\title{
Polycythemia Vera
}

\section{INCREASED EXPRESSION OF NORMAL COMMITTED GRANULOCYTIC STEM CELLS IN VITRO AFTER}

\author{
EXPOSURE OF MARROW TO TRITIATED THYMIDINE
}

\author{
Jack W. Singer, Philip J. Fialkow, John W. Adamson, Laura Steinmann, \\ CONNIE ERNST, SCOTT MURPHY, and KENNETH J. KopeCKy, Sections of \\ Oncology, Medical Genetics, and Hematology, Medical Service, Veterans \\ Administration Medical Center, Seattle, Washington 98108; Departments of \\ Medicine and Genetics, University of Washington, Seattle, Washington 98195; \\ Cardeza Foundation for Hematologic Research, Jefferson Medical College, \\ Philadelphia, Pennsylvania, 19107; and the Program in Epidemiology and \\ Biostatistics, Fred Hutchinson Cancer Research Center, Seattle, Washington \\ 98104
}

A B S T R A C T In previous studies of two patients with polycythemia vera (PV) and heterozygous at the $\mathrm{X}$-linked locus for glucose-6-phosphate dehydrogenase (G-6-PD), only type A isoenzyme was found in nonlymphoid hematopoietic cells. However, some granulocytic and erythrocytic colonies grown in vitro had type B G-6-PD and therefore arose from presumably normal progenitors. In this study we exposed marrow cells from these same two patients to highspecific activity tritiated thymidine $\left({ }^{3} \mathrm{HTdR}\right)$ before culture to kill cells actively synthesizing DNA. Individual granulocytic colonies were plucked and tested for G-6-PD after $14 \mathrm{~d}$ of culture. The frequency of type $B$ colonies rose after exposure to ${ }^{3} \mathrm{HTdR}$ from $8 / 101$ to $11 / 36$ in patient 1 and from $0 / 32$ to $6 / 31$ in patient 2 $(P<0.003)$. No increase in the frequency of normal erythroid bursts after ${ }^{3} \mathrm{HTdR}$ exposure was seen, implying that in PV, early granulopoiesis, and erythropoiesis are regulated differently. The results demonstrated that only type A granulocytic colonies, arising from the abnormal clone, were removed by the ${ }^{3} \mathrm{HTdR}$. In addition, for patient 2 , statistical analysis indicated there was an absolute increase in normal granulocytic colonies detected in culture. Thus, PV clonal colonyforming units in culture (CFU-C) cycle more rapidly

\footnotetext{
A portion of this study was presented at the Annual Meeting of the American Society of Hematology and has been published in abstract form (1978. Blood. 52[Suppl. 1]: 232.).

Received for publication 2 April 1979 and in revised form 22 June 1979.
}

than do normal CFU-C and may suppress proliferation of normal CFU-C in vitro.

\section{INTRODUCTION}

Polycythemia vera (PV), ${ }^{1}$ a chronic myeloproliferative disorder characterized by generalized marrow hyperplasia was previously shown with glucose-6-phosphate dehydrogenase (G-6-PD) markers to arise in a pluripotent stem cell (1). Because of random inactivation of one $\mathrm{X}$-chromosome, which occurs in each $\mathrm{XX}$ somatic cell, tissues of females heterozygous at the $\mathrm{X}$-linked G-6-PD locus for the common gene $\left(\mathrm{Gd}^{\mathrm{B}}\right)$ and a variant such as $\mathrm{Gd}^{\mathrm{A}}$, have two populations of cells-one synthesizing type $B$ and the other type A enzyme. In a study of two G-6-PD heterozygotes with PV, normal tissues displayed both $\mathrm{B}$ and $\mathrm{A}$ enzymes in nearly equal amounts, but peripheral blood erythrocytes, granulocytes, and platelets showed only a single enzyme, type A. These findings provide formal confirmation of the stem cell origin of PV and suggest that the disease was clonal at the time of study.

To determine whether normal committed stem cells were present in these patients, the isoenzyme types of individual marrow colonies grown in semisolid media was determined (2). In cultures that contained

${ }^{1}$ Abbreviations used in this paper: BFU-E, burst-forming units; CFU-C, colony-forming units in culture; CSF, colonystimulating factor; ESF, erythropoietin, G-6-PD, glucose-6phosphate dehydrogenase; ${ }^{3} \mathrm{HTdR}$, tritiated thymidine; PV, polycythemia vera. 
no added erythropoietin (ESF), all erythroid colonies displayed only the isoenzyme found in the PV peripheral blood cells (G-6-PD type A), and presumably arose from the PV clone. However, with increasing concentrations of ESF, colonies of isoenzyme type B were found. The cells giving rise to these colonies presumably represented the progeny of residual normal stem cells whose terminal maturation had been suppressed in vivo. Granulocytic colonies displaying type $B$ isoenzyme were also found under identical culture conditions.

$2 \mathrm{yr}$ later, these same two patients have been restudied to further examine aspects of hematopoietic regulation. This report describes the differential effect of removing rapidly dividing committed stem cells with tritiated thymidine $\left({ }^{3} \mathrm{HTdR}\right)$. The results indicate that early granulopoiesis and erythropoiesis are regulated differently and suggest that in some patients, products of the neoplastic clone suppress the in vitro expression of normal colony-forming units in culture (CFU-C).

\section{METHODS}

The clinical status of the two patients at the time of this study is detailed in Table I. Patient 1 was studied on the Clinical Research Center of the University of Washington Hospital. Marrows were aspirated into alpha medium (Flow Laboratories, Inc., Rockville, Md.) that contained $100 \mathrm{U} / \mathrm{ml}$ of preservative-free heparin. Cells from patient 2 were aspirated in Philadelphia, shipped to Seattle, and incubated overnight at $37^{\circ} \mathrm{C}$ in Eagle's minimal essential medium (MEM) (Microbiological Associates, Walkersville, Md.) with $10 \%$ fetal calf serum.

The cells were washed twice in Eagle's MEM, suspended in $1 \mathrm{ml}$ of thymidine-free alpha medium, and either $200 \mu \mathrm{c} / \mathrm{ml}$ of high-specific activity ${ }^{3} \mathrm{HTdR}(26 \mathrm{Ci} / \mathrm{mM})$ or an equivalent amount of unlabeled thymidine was added (3). The suspensions were incubated for $20 \mathrm{~min}$ in a $37^{\circ} \mathrm{C}$ water bath. Cellular uptake of labeled thymidine incorporation was stopped by the addition of cold Eagle's MEM with an excess of unlabeled thymidine. The cells were then washed twice in cold Eagle's MEM that contained $20 \%$ fetal calf serum and $100 \mu \mathrm{g} / \mathrm{ml}$ of unlabeled thymidine and plated at $2 \times 10^{5}$ cells $/ \mathrm{ml}$ for granulocytic colony growth. Colony-stimulating factor (CSF) was provided by either a feeder layer of peripheral blood leukocytes immobilized in $0.5 \%$ agar (4), or with PHA-conditioned medium (5). The plating mixture consisted of $20 \%$ fetal calf serum and $0.8 \%$ methyl cellulose (MCB; Norwood, Ohio) in alpha medium. Erythroid colonies were grown under conditions described (2) in the presence of 5 and $10 \mathrm{U} / \mathrm{ml}$ of sheep plasma ESF (Step III; Connaught Laboratories, Toronto, Canada). The plates were incubated $10-14 \mathrm{~d}$ in a humidified $5 \% \mathrm{CO}_{2}, 95 \%$ air incubator and the colonies were counted with an inverted microscope.

The overall ${ }^{3} \mathrm{HTdR}$ suicide rate was calculated as the percentage of colony loss after the cells were exposed to ${ }^{3} \mathrm{HTdR}$. The plates were counted and individual colonies were plucked and electrophoresed for G-6-PD as described (2). Erythroid colonies derived from erythroid burst-forming units (BFU-E), which contained $10^{2}-10^{4}$ cells, were harvested on days 10-12 of culture; granulocytic colonies were harvested after $14 \mathrm{~d}$ of culture. All colonies that could be seen in a plate under a dissecting microscope at $\times 25$ were electrophoresed.

\section{RESULTS}

As in the prior study (1), erythrocytes, granulocytes, and platelets when directly tested showed only type A isoenzyme.

Table II gives the results of marrow erythroid and granulocytic colony growth before and after exposure to ${ }^{3} \mathrm{HTdR}$. The losses of granulocytic colonies after marrow cells were exposed to ${ }^{3} \mathrm{HTdR}$ were 41 and $52 \%$

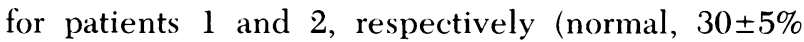
$[ \pm$ SEM] $) .{ }^{2}$ The losses for BFU-E were 41 and $69 \%$, respectively, as compared to a normal mean value of $39 \pm 6 \%$. $^{3}$

Colony electrophoresis results are shown in Table III. In both patients, the proportion of type B granulocytic colonies grown from ${ }^{3} \mathrm{HTdR}$-exposed cells was significantly greater than the proportion from control cells $(P=0.002$ by the Yates corrected chi-squared approximation of Fisher's exact test for patient 1 , and $P=0.003$ by Fisher's exact test for patient 2 ). For erythroid bursts, however, no significant effect on the frequency of B-type colonies was seen after exposure of cells to ${ }^{3} \mathrm{HTdR}$.

Because the proportions of A:B G-6-PD in normal tissues from both patients are $1: 1$, it can be assumed that the frequency of normal colonies that typed as A was equal to that of B colonies. Therefore, the estimated proportions of granulocytic colonies from normal stem

\footnotetext{
${ }^{2}$ Singer, J. W. Unpublished data.

${ }^{3}$ Adamson, J. W. Unpublished data.
}

TABLE I

Clinical Data

\begin{tabular}{|c|c|c|c|c|c|}
\hline Patient & $\begin{array}{c}\text { Year of } \\
\text { diagnosis }\end{array}$ & Hemoglobin & Leukocyte & Platelet & Treatment \\
\hline & & $\mathrm{g} / 100 \mathrm{ml}$ & count $/ m^{3}$ & count $/ m m^{3}$ & \\
\hline 1 & 1972 & 15.8 & 8,300 & 260,000 & $\begin{array}{l}\text { Intermittent chlorambucil (no } \\
\text { medication for } 2 \text { mo before study) }\end{array}$ \\
\hline 2 & 1968 & 11.1 & 35,400 & 553,000 & Phlebotomy only \\
\hline
\end{tabular}


TABLE II

Effect of Exposure to ${ }^{3} \mathrm{HTdR}$ on Colony Growth

\begin{tabular}{|c|c|c|c|}
\hline Patient & $\begin{array}{l}\text { Granulocytic } \\
\text { colonies }\end{array}$ & $n$ & $\begin{array}{c}\text { Erythroid } \\
\text { bursts }\end{array}$ \\
\hline \multicolumn{4}{|l|}{1} \\
\hline Control & $29 \pm 4( \pm \text { SEM })^{*}$ & 4 & $10.6 \pm 1.2$ \\
\hline${ }^{3} \mathrm{HTdR}$ & $17 \pm 1$ & 4 & $6.2 \pm 1.4$ \\
\hline Percent loss & $41 \%$ & & $41 \%$ \\
\hline \multicolumn{4}{|l|}{2} \\
\hline Control & $19 \pm 5$ & 4 & $19 \pm 2$ \\
\hline${ }^{3} \mathrm{HTdR}$ & $9 \pm 2$ & 6 & $6 \pm 2$ \\
\hline Percent loss & $52 \%$ & & $69 \%$ \\
\hline
\end{tabular}

* Colonies $/ 10^{5}$ marrow cells.

cells detected from ${ }^{3} \mathrm{HTdR}$-exposed cells were $22 / 36$ or $61 \%$ for patient 1 and $12 / 31$ or $39 \%$ for patient 2 . The corresponding estimated frequencies from control cultures are 16 and $0 \%$ for patients 1 and 2 , respectively. The estimated frequencies for normal erythroid bursts from ${ }^{3} \mathrm{HTdR}$-exposed cells were 15 and $0 \%$ for patients 1 and 2 , respectively, and 21 and $0 \%$ in the control cultures.

To determine whether the observed increase in type B granulocytic colonies (presumably of normal stem cell origin) after exposure of cells to ${ }^{3} \mathrm{HTdR}$ resulted from an absolute increase in the production of type $B$ colonies, estimates of the mean numbers of type $B$ granulocytic colonies per plate were made. For patient 1 the means are 2.75 and 2.67 in ${ }^{3} \mathrm{HTdR}$ exposed and control cultures, respectively. These means are not significantly different $(P=0.43$ by the conditional test for Poisson means in a hypothetical ratio; see details of statistical methods in Appendix). For patient 2, however, the estimated means of 1.0 and 0.0 are significantly different $(P=0.047)$.

TABLE III

G-6-PD Phenotypes of Colonies before and after Exposure to ${ }^{3} \mathrm{HTdR}$

\begin{tabular}{|c|c|c|c|c|}
\hline \multirow[b]{2}{*}{ Patient } & \multicolumn{2}{|c|}{ Control } & \multicolumn{2}{|c|}{${ }^{3} \mathrm{HTdR}$} \\
\hline & A & B & A & B \\
\hline \multicolumn{5}{|c|}{ Granulocyte colonies } \\
\hline 1 & $93 *$ & 8 & 25 & $11 \S$ \\
\hline 2 & 32 & 0 & 25 & $6 t$ \\
\hline \multicolumn{5}{|c|}{ Erythrocytic colonies } \\
\hline 1 & 42 & 5 & 48 & 4 \\
\hline 2 & 29 & 0 & 24 & 0 \\
\hline
\end{tabular}

* Number of colonies analyzed by specific G-6-PD isoenzyme type.

$\ddagger P=0.003$.

$\S P=0.002$.

\section{DISCUSSION}

In prior studies of marrow regulation in PV, only erythroid colonies with the G-6-PD type characteristic of the PV clone (type A) formed in culture in the absence of added ESF. However, as the concentration of ESF was increased, there were dose-related increases in type B colonies to 28 and $21 \%$ for patients 1 and 2 , respectively (2). These colonies arose from a presumably normal stem cell population. When granulocytic colonies were analyzed from the same cultures, even though the source of CSF was suboptimal, B-type colonies arising from presumably normal CFU-C were also found (40\% for patient 1 and $10 \%$ for patient 2 ). If these progenitors gave rise to mature cells, type B cells would have been detectable when peripheral blood erythrocytes and granulocytes were directly tested. However, since only type A enzyme was found in peripheral blood cells, the progenitors for these type $\mathrm{B}$ colonies presumably were normal committed stem cells whose maturation was suppressed in vivo.

To determine how in vivo suppression of normal stem cell differentiation is mediated in $\mathrm{PV}$, the cell cycle characteristics of CFU-C and BFU-E were studied with ${ }^{3} \mathrm{HTdR}$. A unique advantage of the use of G-6-PD as a marker is that it allows independent calculation of the cell cycle kinetics of the PV and normal committed stem cells. Thus, after the marrow cells were exposed to high-specific activity ${ }^{3} \mathrm{HTdR}$, which selectively kills cells actively synthesizing DNA, an increase in the frequency of normal granulocytic colonies was found in both patients. Calculated losses for the PV clonal granulocytic colonies after ${ }^{3} \mathrm{HTdR}$ are 68 and $82 \%$ for patients 1 and 2, respectively. None of the normal colonies were lost.

Two nonmutually exclusive mechanisms for the in vivo suppression of normal CFU-C can be tested by analysis of the data: (a) CFU-C from the PV clone are less sensitive than are normal CFU-C to a physiologic but as yet uncharacterized feedback control mechanism; therefore, they cycle more rapidly than their normal counterparts. Exposure of marrow cells to ${ }^{3} \mathrm{HTdR}$ selectively eliminates the abnormal (or PV) CFU-C that are synthesizing DNA without affecting the resting, normal CFU-C. This mechanism alone could explain the findings if the apparent increase in frequency of normal colonies were accounted for solely by the loss of abnormal colonies. (b) Proliferation of PV cells, either directly by cell-cell interaction or indirectly by elaboration of a substance, selectively inhibits the growth of normal CFU-C. Inhibition would be eliminated after marrow cells were exposed to ${ }^{3} \mathrm{HTdR}$. This mechanism would be favored if there were an absolute increase in the frequency of normal 
CFU-C, i.e., if the increase was substantially greater than that expected from just the loss of the abnormal, rapidly cycling PV CFU-C.

All CFU-C killed by ${ }^{3} \mathrm{HTdR}$ were from the PV clone. If the hypothesis that the increase in type $\mathrm{B}$ colonies was solely because of loss of abnormal CFU-C is correct, then for patient $1,14 \%$ of the colonies after exposure to ${ }^{3} \mathrm{HTdR}$ should be type B. However, the observed frequency of type B colonies was $31 \%$. Similarly, in patient 2 , the expected frequency of type B colonies after ${ }^{3} \mathrm{HTdR}$ exposure is $<5 \%$, but the observed frequency was $19 \%$. When the data were analyzed statistically, however, a significant absolute increase was found only for patient $2(P<0.05)$. Thus, for this patient the data support the second hypothesis, i.e., that the increase in normal CFU-C could not be accounted for solely by a decrease in CFU-C derived from the PV clone. PV clonal CFU-C cycle more rapidly than do normal CFU-C and probably suppress proliferation of normal CFU-C in vitro by an unknown mechanism. When the PV clonal cells were removed selectively by ${ }^{3} \mathrm{HTdR}$, the growth of normal cells was no longer suppressed.

Although only A-type CFU-C were killed by ${ }^{3} \mathrm{HTdR}$, some CFU-C from the neoplastic clone proliferated in culture (39 and $61 \%$ for patients 1 and 2 , respectively). However, proliferation of these progenitors did not suppress the growth of type B, presumably normal, granulocytic colonies. This relative lack of suppression by residual neoplastic CFU-C in the culture dishes might be a result of the fact that inhibition of normal cell growth is dependent on cell-cell interaction between neoplastic cells and the normal CFU-C. Because of low cell density in the dishes and the semisolid supporting media, significant cell-cell interaction did not occur. A second possibility is that after B-type CFU-C start to proliferate, they no longer respond to inhibitors released by the cycling neoplastic cells. Thus, after exposure to ${ }^{3} \mathrm{HTdR}$, actively dividing Atype neoplastic cells that had been inhibiting B-type CFU-C were lost and only the resting, neoplastic cells remained. Therefore, normal cells were released from inhibition at the start of the semisolid cultures. If cycling B-type CFU-C cells were no longer sensitive to inhibitors from the neoplastic cells, the proliferation of the remaining A-type CFU-C in the cultures would have no inhibitory effect.

This report adds to the previous studies of in vitro regulation of hematopoiesis in $\mathrm{PV}(2,6,7)$. Although only high concentrations of ESF increased the percentage of normal erythroid colonies, even suboptimal sources of CSF stimulated the growth of normal granulocytic colonies (2). In this study, removal of rapidly dividing cells resulted in the selective loss of abnormal CFU-C but not of BFU-E. Thus, the regula- tory mechanisms by which the neoplastic clone suppresses normal committed erythrocytic and granulocytic stem cell growth appear different.

It is of interest to use G-6-PD to study in vitro regulation of hematopoiesis in other myeloproliferative disorders shown to have a clonal origin such as chronic myelogenous leukemia $(8,9)$, agnogenic myeloid metaplasia $(10,11)$, and acute leukemias $(12,13)$ to determine mechanisms for suppression of normal stem cell expression. A preliminary study of in vitro granulopoiesis in five G-6-PD heterozygotes with chronic myelogenous leukemia failed to detect residual normal stem cells despite electrophoresis of over 1,300 colonies (14). Thus, the pathogenesis, the rapidity of progression, or both in chronic myelogenous leukemia may be different from that in PV.

Sequential studies of $\mathrm{PV}$ patients treated with agents that selectively kill more rapidly dividing cells should be done. The in vitro data indicate that at least for granulopoiesis these agents selectively kill cells from the neoplastic clone and that this might allow for a greater degree of expression of normal stem cells, a finding that might have therapeutic relevance.

\section{APPENDIX}

Statistical methods. For purposes of statistical analysis, the number of electrophoresed colonies of each type (granulocytic or erythrocytic) were presumed to follow Poisson probability distributions, the means of which are expressed as numbers of colonies per plate and can depend on stem cell origin (PV or normal [N]), G-6-PD type (A or B), and ${ }^{3} \mathrm{HT} d \mathrm{R}$ status (exposed [E] or unexposed [U]). The mean number of granulocytic colonies of PV stem cell origin (which are assumed to type exclusively as A) cultured on unexposed plates is denoted $G(P V, U)$. The mean for colonies of normal stem cell origin is presumed to be the same for types A and B, say $G(N, U)$. Because stem cell status of colonies cannot be assessed, we must deal with the observable numbers of granulocytic colonies by G-6-PD type, which on unexposed plates are therefore Poisson random variables with means $G(P V, U)+G(N, U)$ for types $A$ and $B$, respectively. Analogously, on exposed plates the mean numbers of type $A$ and $B$ granulocytic colonies are $\mathrm{G}(\mathrm{PV}, \mathrm{E})+\mathrm{G}(\mathrm{N}, \mathrm{E})$ and $\mathrm{G}(\mathrm{N}, \mathrm{E})$, respectively, and similar expressions hold for erythroid colonies.

\section{ACKNOWLEDGMENTS}

This work was supported by the Medical Research Service of the Veterans Administration and by grants CA 18029, CA 16448, GM 15253, AM 19410, and CA 15704 from the National Cancer Institute and the Institutes of General Medical Sciences and Arthritis, Metabolism, and Digestive Diseases, National Institutes of Health. A portion of this work was conducted through the Clinical Research Center Facility of the University of Washington, supported by the National Institute of Health (grant RR-37).

\section{REFERENCES}

1. Adamson, J. W., P. J. Fialkow, S. Murphy, J. F. Prchal, and L. Steinmann. 1976. Polycythemia vera: stem cell and 
probable clonal origin of the disease. N. Engl.J. Med. 295: 913-916.

2. Prchal, J. F., J. W. Adamson, S. Murphy, L. Steinmann, and P. J. Fialkow. 1978. Polycythemia vera: The in vitro response of normal and abnormal stem cell lines to erythropoietin. J. Clin. Invest. 61: 1044-1047.

3. Singer, J. W., and J. W. Adamson. 1976. Steroids and hematopoiesis. III. The response of granulopoietic and erythroid colony forming cells to steroids of different classes. Blood. 48: 855-864.

4. Pike, B., and W. A. Robinson. 1970. Human bone marrow growth in agar-gel. J. Cell. Physiol. 76: 78-83.

5. Ruscetti, F. W., and P. A. Chervenick. 1975. Regulation of release of colony-stimulating activity from mitogenstimulated lymphocytes. J. Immunol. 114: 1513-1517.

6. Prchal, J. F., and A. A. Axelrad. 1974. Bone marrow response in polycythemia vera. N. Engl.J. Med. 289: 1382.

7. Zanjani, E. D., J. D. Lutton, R. Hoffman, and L. R. Wasserman. 1977. Erythroid colony formation by polycythemia vera bone marrow in vitro. J. Clin. Invest. 59: 841-848.

8. Fialkow, P. J., S. M. Gartler, and A. Yoshida. 1967. Clonal origin of chronic myelocytic leukemia in man. Proc. Natl. Acad. Sci. U. S. A. 58: 1468-1471.
9. Fialkow, P. J., R. J. Jacobson, and T. Papayannopoulou. 1977. Chronic myelocytic leukemia: clonal origin in a stem cell common to the granulocyte, erythrocyte, platelet and monocyte/macrophage. Am. J. Med. 63: 125-132.

10. Kahn, A., J. F. Bernard, D. Cottreau, J. Marie, and P. Boivin. 1975. Gd (-) Abrami: a deficient G-6-PD variant with hemizygous expression in blood cells of a woman with primary myelofibrosis. Humangenetik. 30: 41-44.

11. Jacobson, R. J., A. Salo, and P. J. Fialkow. 1978. Agnogenic myeloid metaplasia: a clonal proliferation of hematopoietic stem cells with secondary myelofibrosis. Blood. 51: 189-194.

12. Wiggins, R. G., R. J. Jacobson, P. J. Fialkow, P. V. Woolley, J. A. MacDonald, and P. S. Schein. 1978. Probable clonal origin of acute myeloblastic leukemia following radiation and chemotherapy of colon cancer. Blood. 52: 659-663.

13. Jacobson, R. J., R. A. Sacher, and P. J. Fialkow. 1978. Clonal presentation of acute leukemia in relapse. Blood. 52: 255. (Abstr.)

14. Singer, J. W., P. J. Fialkow, L. Steinmann, V. Najfeld, S. J. Stein, and W. A. Robinson. 1979. Chronic myelocytic leukemia: failure to detect residual normal committed stem cells in vitro. Blood. 53: 264-268. 